\title{
UVODNIK
}

\section{ANTIRASISTIČNE PERSPEKTIVE V IZOBRAŽEVANJU}

Socialni psiholog in raziskovalec konfliktov z Univerze v Bielefeldu v Nemčiji, Andreas Zick, ki je lansko leto prejel nemško znanstveno priznanje za komuniciranje na področju raziskav diskriminacije in nasilja $v$ družbi, s svojimi sodelavci že vrsto let dokazuje, da se z višanjem izobrazbe in večjo blaginjo v družbi predsodki, stereotipi in diskriminacija ne zmanjšujejo (Zick, Pettingrew in Wegner, 2008; Küpper in Zick, 2010; Zick, 2015a, 2015b; Carvacho idr., 2013). S sodelavci je na podlagi kvantitativnih raziskav, narejenih v različnih evropskih državah, ugotovil, da pripadnost določenemu družbenemu razredu ni statistično značilno povezana z dovzetnostjo za krepitev predsodkov in nestrpnosti. Na primeru Nemčije so dokazali, da se je v desetletnem obdobju, ki sta ga presekali finančna in gospodarska kriza leta 2008, znatno povečala prav nestrpnost v višjih družbenih razredih (Zick, 2015b), kar je v pričujoči številki Andragoških spoznanj v okviru kritičnega opismenjevanja dijakov mariborskih gimnazij zaznala in ugotavljala tudi Urška Breznik. Tudi drugi statistični podatki kažejo rast različnih oblik organiziranega sovraštva: Nemčija je samo leta 2015 zabeležila prek 550 napadov na azilne domove, v letu 2016 kar 3.500 napadov na begunce in migrante, pri čemer je bilo ranjenih več kot 500 ljudi, med katerimi so bili tudi otroci.

Prizori iz devetdesetih let 20. stoletja, ko so takrat še prepovedane skrajne desničarske skupine v Nemčiji zažigale azilne domove in ko je bilo ulično izživljanje nad priseljenci, migranti, prosilci za azil, begunci, Turki, Albanci, Romi in drugimi marginaliziranimi skupinami tako rekoč vsakdanja kriminalna folklora, so se konec leta 2015 ob množičnih migracijah skozi Evropo vrnili. Danes smo v Nemčiji kot tudi v drugih državah EU priča številnim novim procesom organiziranega sovraštva in nasilja, ki prek uličnih, institucionalnih, strankarskih, legalnih in drugih sfer in kanalov vstopajo v življenja vseh - državljanov in nedržavljanov. Zick (2015a, 2015b) na primeru Nemčije ugotavlja, da kar 23 odstotkov vprašanih meni, da je »bes državljanov proti priseljevanju absolutno razumen«; »da je treba omejiti tuje vplive na nemško kulturo«, pa 40 odstotkov vprašanih. Še več, kar 58 odstotkov vprašanih se strinja s trditvijo, da »v Nemčiji ne moreš reči kaj slabega o priseljencih in Judih, ne da bi te označili za rasista«, od tega se jih kar 80 odstotkov šteje za tolerantne. Tovrstnim izjavam so ne le v Nemčiji, temveč tudi drugod po Evropi najbolj naklonjeni mladi (18-30 let) in starejši (60+). 
V tako izraženih predsodkih in stereotipih se zrcalijo specifični sentimenti in emocije, dovtipi in strahovi, kar poskuša Nemčija predvsem zaradi svoje nacistične zgodovine prehajati z večjo zadržanostjo in skrbjo do tovrstnih pojavov (oziroma gre vsaj na videz za bolj restriktivno politiko in večjo občutljivost do teh vprašanj, kar z avstrijske perspektive potrjuje tudi prispevek Annette Sprung v tej tematski številki). In na drugi strani, kot kažejo raziskave iz Bielefelda, je Nemčija tudi vse bolj prepredena s sovraštvom in težnjami po nasilju, ki jih zaznavajo tako raziskave kot kriminalistična in druga poročila. A bolj kot vse to je presenetljivo, da se predsodki in stereotipi tako v Nemčiji kot tudi v Sloveniji in drugod v Evropi še naprej napajajo iz podobnih izhodišč kot pred 50, 60, 70 leti, ki jih je prvi celostno zapopadel Adorno (1999) oziroma raziskovalci v okviru frankfurtske šole. Četudi naj bi bila rasna večvrednost v nacistični ideologiji zgodovinsko zavržena in »premagana«, pa je po sodobnih raziskovanjih izvor diskriminacij in zatiranj še naprej »neenaka vrednost ljudi«, ki izhaja iz avtoritarnih, konzervativnih in drugih ideologij prevlade in prisvojitve. Zick v kontekstu neenake vrednosti ljudi in obravnave antisemitskih stališč razvije »sindrom organiziranega sovraštva « (the syndrom of group-based enmity), ki sloni na implicitnem mišljenju (Zick idr., 2008; Zick, 2015a, 2015b). Sindrom se ne napaja v kolektivnih ali pa v konsenzualno potrjenih in izraženih stališčih, prepričanjih, vrednotah itn., temveč je plod implicitnega mišljenja, torej tega, da mislimo, da bodo ljudje iz moje družbene skupine na določeno vprašanje (recimo o migracijah, priseljencih, rasizmu, kaj je narobe s svetom, o napredku, o homogenosti nacionalne kulture itn.) odgovorili enako kot jaz. In ta common sense - to prevladujoče mišljenje - ne napaja zgolj skrajno konzervativnih, populističnih in desničarskih pogledov, ampak vstopa v levičarske, libertarne idr. bolj subtilne in osvobajajoče prakse, kajti hegemonija kapitalizma je za seboj pustila radikalno opustošene skupnosti, tako rekoč individualizirane, izolirane in v preživetje ujete posameznike, ki politiko razumejo in prakticirajo zgolj prek političnega zabavljaštva (political entertainment). Tega pa vodi kapital prek nacionalnih parlamentov, medijev in drugih kvazi oblastnikov.

Zick (2015b) opozarja na proces radikalizacije, v katerem se uspeva skrajno populističnim in ekstremno desničarskim diskurzom približevati skrajno levičarskim ali celo libertarnim pogledom: skupni so jim razočaranje nad demokracijo, nemočjo ljudi, manipulacijo elit, nad korupcijo in klientelizmom, nezaupanje $\mathrm{v}$ sistem, upor proti bogatim, zavračanje »lažnivih « medijev itn. Gre za neke vrste implozijo dveh skrajnosti: radikalne demokracije in organizirane sovražnosti ter za radikalizacijo diskurzov na obeh polih. Tem diskurzom populistične, nacionalistične in sovražne skupine in stranke v Nemčiji dodajajo še »Wir sind das Volk« (kar nakazuje na reafirmacijo nemške identitete), »Mi imamo prav «, »Mi smo tolerantni «, »Mi smo mladi in pripravljeni na boj« ... Na sentimente, ki se naslanjajo na izrojeno demokracijo, se lepijo še emocionalni elementi, to je upravičevanje nasilja kot izjeme, sovraštva, besa in jeze. Podatki, ki jih razkriva Zick s svojimi sodelavci, ter statistični podatki o drastičnem razmahu populističnih, nacionalističnih desničarskih strank, ki delujejo na nacionalni ravni (kot denimo stranka Besni državljani (Bürger in Wut), katere poslanstvo je nacionalno krščanstvo) ali tudi na ravni EU (kot denimo v Nemčiji ustanovljeno antievropsko evropsko gibanje Pegida - Patriotische 
Europäer gegen die Islamisierung des Abendlandes), in organiziranih sovražnih skupin, ki delujejo javno in legitimno, postajajo več kot skrb zbujajoči, a brez ustreznega odziva, sploh pa brez pravega odziva tako nacionalnih kot mednarodnih politik, sodstva oziroma mednarodnih pravnih institucij kot tudi znanosti.

Zick ugotavlja, da sodobna znanost in raziskovanje ob povečanju organiziranega sovraštva ponujata zgolj specializirane konference, ki se lotevajo posameznih, partikularnih fenomenov, ne pa celote, na katero je usmerjeno organizirano sovraštvo. Najmanj, kar lahko temu dodamo, je, da se sodobne raziskave rasizma in fašizma ne lotevajo v vsem njunem obsegu in kompleksnosti, v vseh njunih brutalnostih, nedoslednostih, protislovnostih in neposrednostih, temveč po drobcih in skozi različne leče opazovanja in obravnavanja fenomena. Kar pa je verjetno še najpomembneje, je to, da družboslovne in humanistične znanosti niti nimajo »rešitev« za odpravljanje sodobnih družbenih problemov - in rasizem in fašizem sta gotovo samo dva od mnogih, ki ju, podobno kot finančne zlome in gospodarske recesije, prepuščamo samorazreševanju oziroma neoliberalnemu korporativnemu upravljanju. Podobna ideologija, ki vodi kapitalistična gospodarstva (ideologija »rasti ali crkni«), je na delu tudi v družbenih procesih (neenaka vrednost ljudi kot sprožilec rasizma in sovraštva). Ker se je zgodovinsko gledano že večkrat pokazalo, kako znanost v času kriz (tudi v času fašizma in nacizma) sledi uradnim ideologijam, četudi producirajo najbolj nehumane pristope in si zastavljajo najbolj nečloveške cilje, bi morali biti danes, opolnomočeni z zgodovinskimi izkušnjami, toliko bolj senzibilni za procese, ki zarisujejo družbeni fašizem (Santos, 2014) tako na globalnih ravneh, kot tudi na ravni $\mathrm{EU}$ in nacionalni ravni.

Sindrom organiziranega sovraštva, ki ponovno poganja korenine v naših družbah, je močno prisoten tudi v izobraževalnih institucijah, še zlasti na univerzah, za katere se predpostavlja, da naj bi ustvarjale razsvetljene kadre, sposobne krepiti razvoj in napredek družbe. Da se je v Sloveniji organizirano sovraštvo udomačilo v srednjih šolah in na fakultetah - med dijaki in študenti kot tudi med zaposlenimi, je doslej opozorilo že veliko iniciativ, s pismi, pobudami, novimi praksami, predavanji itn., katerih pobudniki so bili dijaki, študenti in angažirani predavatelji. Četudi so bili tovrstni poskusi številni, pomembni in odmevni, so bili kratke sape. A vendarle so bili poleg aktivne civilne družbe, ki se zoperstavlja represivnim in diskriminacijskim politikam aparatov države, edini odgovor na (svoje lastne oziroma notranje) rasizme, nestrpnost itn., ki vznikajo v visokem šolstvu oziroma v okviru izobraževalnih sistemov. Tudi v raziskavah med nemškimi študenti in študentkami raziskovalci v Bielefeldu nimajo spodbudnih rezultatov. Ko so dvema različnima skupinama svojih študentov razdelili vprašalnik o antisemitizmu, so eni skupini v naslovu vprašalnika eksplicitno napisali, kaj je namen raziskave (»Vprašalnik o antisemitizmu«), druga skupina pa je prejela vprašalnik brez vsakršne označbe (torej je bil naslov le »Vprašalnik«). Raziskovalci so pričakovali, da bodo študentje, ki so bili s poimenovanjem vprašalnika opozorjeni na namen raziskave, bolj previdni v odgovorih in da bodo posledično izrazili manj stereotipov, a izkazalo se je, da med skupinama ni bilo nikakršne razlike. Ugotovili so tudi, da so imeli študentje, ki so izražali nestrinjanje s tezo, 
da lahko »svobodno povedo svoje mnenje na univerzi«, signifikantno močneje izražen antisemitizem, kot pa tisti, ki niso čutili zadržkov glede svobodnega izražanja na univerzi.

Več kot jasno je, da je bilo samo v zadnjem letu ali dveh povodov in razlogov za tokratno tematsko številko Andragoških spoznanj, ki obravnava prav antirasistično perspektivo v izobraževanju in za izobraževanje, ogromno. Žica. Militarizacija. Nehumano ravnanje z migranti in begunci. Pravila izjem. Sprememba zakona o tujcih. Nasilni izgon sirske družine Korba-Sulejman kljub močni socialni mreži ... Doma in v tujini je bilo o tej temi več zanimivih posvetov in konferenc, pa tudi pobud in reakcij intelektualcev. Omrežje Med globalnim in lokalnim: učenje odraslih in skupnosti (Between global and local: adult learning and communities), ki deluje v okviru ESREA (European Society for Research on the Education of Adults), je konec maja v Vroclavu na Poljskem pripravilo konferenco o migracijah, ki je $\mathrm{v}$ ospredje postavila prav angažirane in emancipatorne pristope $\mathrm{v}$ izobraževanju, prek izobraževanja in $\mathrm{v}$ raziskovanju. V Sloveniji sicer imamo nekaj pomembnih znanstvenih revij, raziskovalnih skupin ali inštitutov, ki se permanentno in prvenstveno ukvarjajo s tematikami, kot so migracije, rasizem, državljanstvo, nestrpnost itn. Zelo malo in kakovostno pa je bilo doslej raziskanega in obravnavanega $\mathrm{z}$ vidika antirasističnih pristopov, praks in perspektiv na družboslovnih in humanističnih področjih. Kar zadeva antirasistične pristope v izobraževanju in za izobraževanje ter $\mathrm{s}$ tem tudi perspektive za bodoče izobraževanje, pa lahko trdimo, da so tovrstni premisleki, če sploh so, obrobni in podreprezentirani. Tudi v tujini najdemo le malo relevantnih avtorjev, ki razvijajo antirasistično izobraževanje v kontekstu interkulturalizma ali pa kritičnih pristopov opismenjevanja, kot denimo Apple (2000), Dilg (1999), Giroux (1983), Kailin (2002), Mirochnik in Sherman (2002), Schugurensky (2010) (druge pomembne piske in pisce antirasistične pedagogike in andragogike omenjajo tudi prispevki v pričujoči številki). Razen nekaj specializiranih tujih revij na temo mirovnih in podobnih študij pravzaprav niti nimamo revij, ki bi se eksplicitno ukvarjale $\mathrm{z}$ antirasističnimi determinantami $\mathrm{v}$ izobraževanju.

Naj v splošnem in znanstvenem prepričanju kar prevladuje mit, da z višanjem izobrazbene in statusne ravni družbenih skupin vplivamo na zmanjševanje predsodkov in diskriminacije, a različni podatki, raziskave, še zlasti pa vsakdanje življenjske prakse v predavalnici, politični in medijski diskurzi, vsakdanje doživljanje spreminjanja sveta prek skupnosti, kjer živimo, prek bodečih žic in uniformiranih enot, ki nad drugorazrednimi državljani in nedržavljani prakticirajo "paradigmo prisvajanja in nasilja « (o čemer v recenziji Santosovih Epistemologij Juga piše Manca Marolt), kar se je v vsej svoji brutalnosti razkrilo pred azilnim domom na Viču v Ljubljani pred begunskim otrokom in njegovo družino ter številnimi podporniki, nam kažejo neko drugo, dokaj alarmantno realnost. Zato se je treba nenehno preizpraševati, kakšno izobraževanje ustvarjamo in ali (ter $\mathrm{v}$ kolikšni meri) naše delo prispeva h krepitvi rasističnih in drugih izključevalnih in diskriminatornih stališč, vrednot in praks v naši družbi. Da sta prav antirasistično učenje in izobraževanje, umeščena v kontekst participativne demokracije (aktivnega sooblikovanja in soodločanja) in interkulturne izmenjave (vzgoje, učenja in izobraževanja, ki poskušajo 
vzpostavljati ravnovesje med spodbujanjem enakosti in spoštovanjem razlik), lahko eden najpomembnejših socializatorjev in resocializatorjev naših družb, najbrž ni treba posebej utemeljevati, sploh ob spoznanju, da so paradigma multikulturnega izobraževanja ter vrsta drugih površinskih in nekritičnih pristopov s poudarjanjem folklore, hrane in prazničnih prireditev, obredij ter festivalov ali pa plesa, obleke in prehranskih navad krepili razlike in solidarnost zamenjevali s humanitarnostjo. Prizadevanja antirasističnih pristopov za izobraževanje in v izobraževanju pa se nedvomno nagibajo k spodbujanju globljih, celostnih analiz in interakcij, $\mathrm{k}$ brezpogojnemu zoperstavljanju diskriminaciji (po načelu ničelne tolerance do rasizma) ter k spodbujanju solidarnosti, tudi ko gre za kognitivno družbeno pravičnost (o čemer inovativno razmišlja Santos, 2014).

Prav v tem smislu že vrsto let prepoznavamo resno potrebo po premišljanju, osvetljevanju in osmišljanju teh bolj angažiranih, kritičnih in emancipatornih pristopov oziroma vidikov, kar poskušamo predstaviti tudi v aktualni številki. $\mathrm{V}$ prvem prispevku filozof Darij Zadnikar preizprašuje sodobni rasizem postkolonialne dobe in njegove nove značilnosti, ki zahtevajo drugačne antirasistične pristope, pri čemer poleg preseganja neoliberalizma poudari vključevanje epistemologij Juga. Podobno se Santosovega prehajanja epistemologij slepote oprime tudi prispevek Marte Gregorčič, ki prek demokratičnega konfederalizma na kurdskih osvobojenih območjih nakaže drugačno obravnavo migracij kot tudi izobraževanja o migracijah prav s soočenjem z možnostjo nastajanja novih epistemologij v središču spopadov globalnih velesil. Nadalje v tretjem prispevku Annette Sprung nakaže, kakšne antirasistične intervencije so poskusili vpeljati avstrijski pedagogi prek institucionalnih sprememb ter kako so bili pri svojih poskusih uspešni. Socialna pedagoginja Špela Razpotnik izriše analizo različnih emancipatornih praks, ki so jih angažirani študenti in študentke ter profesorji in profesorice Pedagoške fakultete v Ljubljani $\mathrm{v}$ zadnjih letih razvili z različnimi izključenimi ali zavrženimi posamezniki, družinami in družbenimi skupinami. Čeprav smo si želeli, da bi se na vabilo k pisanju prispevkov o emancipatornih in antirasističnih praksah v predavalnicah ali na terenu odzvalo še več pedagogov ali andragogov, pa upamo, da bo katera od prihodnjih številk lahko ponudila še več premislekov o tako pomembnih in za naš čas tudi radikalnih temah. Tokratna Andragoška spoznanja prinašajo še prispevek Sare Brezigar o stanju in izzivih etnične diskriminacije v slovenskem šolstvu ter intervju z Urško Breznik, ki razkriva pedagoške pristope pri kritičnem opismenjevanju.

\section{Marta Gregorčič}

\section{LITERATURA}

Adorno, T. W. (1999). Avtoritarna osebnost. V M. Nastran Ule (ur.), Predsodki in diskriminacije: izbrane socialno-psihološke študije (str. 126-156). Ljubljana: Znanstveno in publicistično središče.

Apple, M. W. (2000). Official Knowledge: Democratic education in a conservative age. New York: Routledge. 
Carvacho, H., Zick, A., Haye, A., González, R., Manzi, J., Kocik, C. in Bertl, M. (2013). On the relation between social class and prejudice: The roles of education, income, and ideological attitudes. European Journal of Social Psychology, 45, 272-285.

Dilg, M. (1999). Race and culture in the classroom: Teaching and learning through multicultural education. New York: Teachers College Press.

Giroux, H. A. (1983). Theory and resistance in education. South Hadley: Bergin in Garvery.

Kailin, J. (2002). Antiracist education: From theory to practice. New York: Rowman in Littlefield Publishers.

Küpper, B. in Zick, A. (2010). Macht Armut menschenfeindlich? Zusammenhänge in acht europäischen Ländern. V W. Heitmeyer (ur.), Deutsche Zustände: Folge 9 (str. 84-105). Frankfurt am Main: Suhrkamp.

Mirochnik, E. in Sherman, D. C. (2002). Passion and pedagogy: Relation, creation, and transformation in teaching. New York: Peter Lang.

Santos, B. de Sousa (2014). Epistemologies of the South. Justice against epistemicide. London in NY: Routledge.

Schugurensky, D. (2010). Introductory Essay: Citizenship learning for and through participatory democracy. V E. Pinnington in D. Schugurensky (ur.), Learning citizenship by practicing democracy: International initiatives and perspectives (str. 1-16). Newcastle upon Tyne: Cambridge Scholars Publishing.

Zick, A., Pettingrew, T. F. in Wegner, U. (2008). Ethnic Prejudice and Discrimination in Europe. Journal of Social Issues, 64(2), 233-251.

Zick, A., Wolf, C., Küpper, B., Davidov, E., Schmidt, P. in Heitmeyer, W. (2008). The syndrom of goups-focused enmity: The interrelation of prejudices tested with multiple cross-sectional and panel data. Journal of Social Issues, 64(2), 363-383.

Zick, A. (2015a). Empirical Observations on Antisemitic Enmity in Europe, predavanje na konferenci SKMA Stockholm (10. november 2015). Pridobljeno s https://vimeo.com/145393097.

Zick, A. (2015b). Group-Focused Enmity and Radicalisation. Predavanje v okviru European Summer School on Prejudice, Genocide, Remembrance, Budimpešta (6. julij 2015). Pridobljeno s https:// www.youtube.com/watch?v=-rfMMOLxUy4. 